Article

\title{
Vitamin D Status and Efficacy of Vitamin D Supplementation in Atopic Dermatitis: A Systematic Review and Meta-Analysis
}

\author{
Min Jung Kim ${ }^{1}$, Soo-Nyung Kim ${ }^{2}$, Yang Won Lee ${ }^{1,3, *}$, Yong Beom Choe ${ }^{1,3}$ \\ and Kyu Joong Ahn 1,3 \\ 1 Department of Dermatology, Konkuk University School of Medicine, Seoul 05030, Korea; \\ mjkimmd@kuh.ac.kr (M.J.K.); cyb@kuh.ac.kr (Y.B.C.); kjahn@kuh.ac.kr (K.J.A.) \\ 2 Department of Obstetrics and Gynecology, Konkuk University School of Medicine, Seoul 05030, Korea; \\ snkim@chol.com \\ 3 Research Institute of Medical Science, Konkuk University, Seoul 05030, Korea \\ * Correspondence: 20050078@kuh.ac.kr; Tel.:+82-2-2030-5172
}

Received: 9 August 2016; Accepted: 24 November 2016; Published: 3 December 2016

\begin{abstract}
Recent literature has highlighted the possible role of vitamin D in atopic dermatitis (AD), and that vitamin D supplementation might help to treat AD. This study determined the relationship between vitamin $\mathrm{D}$ level and $\mathrm{AD}$, and assessed the efficacy of vitamin $\mathrm{D}$ supplementation. We searched the MEDLINE, EMBASE, and Cochrane databases up to May 2015. Observational studies and randomized controlled trials were included based on the available data on the serum 25-hydroxyvitamin D (25(OH)D) level and quantified data available for severity assessed using the Scoring Atopic Dermatitis (SCORAD) index or Eczema Area and Severity Index (EASI) score. Compared with healthy controls, the serum $25(\mathrm{OH}) \mathrm{D}$ level was lower in the AD patients of all ages (standardized mean difference $=-2.03 \mathrm{ng} / \mathrm{mL} ; 95 \%$ confidence interval $(\mathrm{CI})=-2.52$ to -0.78 ), and predominantly in the pediatric AD patients (standardized mean difference $=-3.03 \mathrm{ng} / \mathrm{mL}$; $95 \% \mathrm{CI}=-4.76$ to -1.29 ). In addition, the SCORAD index and EASI score decreased after vitamin D supplementation (standardized mean difference $=-5.85$; 95\% CI $=-7.66$ to -4.05 ). This meta-analysis showed that serum vitamin D level was lower in the AD patients and vitamin D supplementation could be a new therapeutic option for AD.
\end{abstract}

Keywords: atopic dermatitis; vitamin D; meta-analysis; systematic review

\section{Introduction}

Atopic dermatitis (AD) is a common and recurring chronic inflammatory disease characterized by pruritus and eczema. It is commonly associated with hypersensitivity to allergens, more frequently with allergic diseases such as allergic rhinitis and asthma [1]. It reportedly affects 5\%-20\% of children and $1 \%-3 \%$ adults worldwide, and its prevalence is increasing in industrialized countries [2]. The pathophysiology of AD is mainly the result of epidermal barrier defectiveness and immune dysregulation [1,3]. The traditional therapeutic options for AD are antihistamine and immune modulatory agents, including topical/oral corticosteroids and topical/oral calcineurin inhibitors. These classic treatments are focused on reducing skin inflammation [4], but their potential side effects and poor patient adherence indicate the importance of finding new therapeutic options. Recent studies have suggested that vitamin D supplementation may be a safe and effective alternative treatment for AD. A Cochrane review provided evidence for the efficacy of dietary vitamin D supplements as a treatment for AD in 2012 [5]. However, only two studies were reviewed, and owing to their low quality, the review could not produce conclusive evidence for the efficacy of vitamin D supplements in AD treatment. 
The present study performed a systematic review and meta-analysis to determine the serum 25-hydroxyvitamin D (25(OH)D) levels in AD patients compared with those in healthy controls. In addition, we reviewed double-blind randomized controlled trials to assess the efficacy of vitamin D supplementation as a treatment for AD by using the Scoring Atopic Dermatitis (SCORAD) index and the Eczema Area and Severity Index (EASI) score.

\section{Materials and Methods}

We conducted this systematic review in accordance with the Preferred Reporting Items for Systematic Reviews and Meta-Analyses statement [6]. We did not register a protocol.

\subsection{Search Strategy and Data Collection}

We performed a systematic review of the MEDLINE, EMBASE, and Cochrane Central Register of Clinical Trials databases up to May 2015 by using the following keywords: (atopic dermatitis OR eczema) AND (vitamin D). The search was limited to human studies. The reference lists of the retrieved articles were reviewed manually.

\subsection{Study Selection and Data Extraction}

The titles and abstracts of the identified articles were checked and independently reviewed by two of the authors (M.K. and Y.L.), with discrepancies resolved by discussion. We included observational studies to determine the association between serum 25(OH)D level and AD. In addition, we included randomized controlled trials to assess the efficacy of vitamin D supplementation as a treatment for $\mathrm{AD}$ patients. The following inclusion criteria were applied: (1) presence of $\mathrm{AD}$; (2) data available for serum 25(OH)D level; and (3) quantified data available for AD severity assessed by use of the SCORAD index or the EASI score. We excluded studies that included pregnant women and cord blood samples. We contacted the investigators of the studies by e-mail when necessary to obtain raw or missing data. However, we excluded articles in the meta-analysis that did not contain sufficient data owing the low response rates.

We extracted the following data from the databases: study characteristics (author(s), year of publication, and study design), patient characteristics (age, serum 25(OH)D levels, and SCORAD indices or EASI scores), and vitamin D supplementation (dosages and durations). When the standard deviations (SD) were not available, the probability value was used to assess the SDs.

\subsection{Quality of Assessment}

The quality of each study was assessed by two of the authors by using the nine-star Newcastle-Ottawa Scales (NOS) for observational studies [7]. Independent case-control studies were included, in accordance with the NOS standard procedure. Nine points were given to the study of highest quality, and studies awarded highest quality were considered as having sufficiently high quality in the meta-analysis.

The risk of bias was assessed using the Cochrane Collaboration Risk of Bias Tool for randomized controlled trials [8]. We assessed the risk of bias, random sequence generation, allocation concealment, blinding of participants and personnel, blinding of the outcome assessment, analysis of incomplete outcome data, selective reporting, and other biases. The two authors (M.K. and Y.L.) rated the included articles independently, and the score was finalized by discussion. The results of the assessments were categorized as follows: "yes" for a low risk of bias, "unclear", and "no" for a high risk of bias.

\subsection{Statistical Analysis}

The mean differences and 95\% confidence intervals (CIs) were calculated from the extracted data. We assessed the heterogeneity across the studies using the $I^{2}$ statistic, which indicates the percentage of the total variation among studies $[9,10]$. A funnel plot was constructed to assess the bias based on 
the standard error [11]. We assessed the interstudy heterogeneity using the $I^{2}$ statistic, such that if $I^{2}$ was $>50 \%$, the assumption of homogeneity was deemed invalid, and the random effects model was applied; otherwise, the fixed model was used. Data analysis was performed using Review Manager 5.3 (The Cochrane Collaboration, The Nordic Cochrane Centre, Copenhagen, Denmark).

\section{Results}

Of the 920 articles that were initially retrieved, 35 were selected for full-text review. Eleven of these selected studies were excluded because they did not fulfill the inclusion criteria. Figure 1 shows the flowchart of the studies as assessed through the review process. Table 1 shows the quality of the observation studies by use of the nine-star NOS, and Figure 2 shows the risk of bias of randomized controlled trials.

Table 1. Assessment of the quality of the included observation studies by using the NewcastleOttawa scale.

\begin{tabular}{ccccc}
\hline \multirow{2}{*}{ Study } & Year & \multicolumn{3}{c}{ Criterion Scores } \\
\cline { 3 - 5 } & & Selection & Comparability & Exposure \\
\hline Samochocki et al. [12] & 2013 & $\star \star \star \star$ & $\star \star$ & $\star$ \\
El Taieb et al. [13] & 2013 & $\star \star \star \star$ & $\star \star$ & $\star$ \\
Noh et al. [14] & 2014 & $\star \star \star \star$ & $\star \star$ & $\star$ \\
Wang et al. [15] & 2014 & $\star \star \star$ & $\star \star$ & $\star$ \\
Cheon et al. [16] & 2015 & $\star \star \star$ & & $\star$ \\
Han et al. [17] & 2015 & $\star \star$ & $\star \star$ & $\star$ \\
Di Filippo et al. [18] & 2015 & $\star \star \star$ & $\star \star$ & $\star$ \\
\hline
\end{tabular}

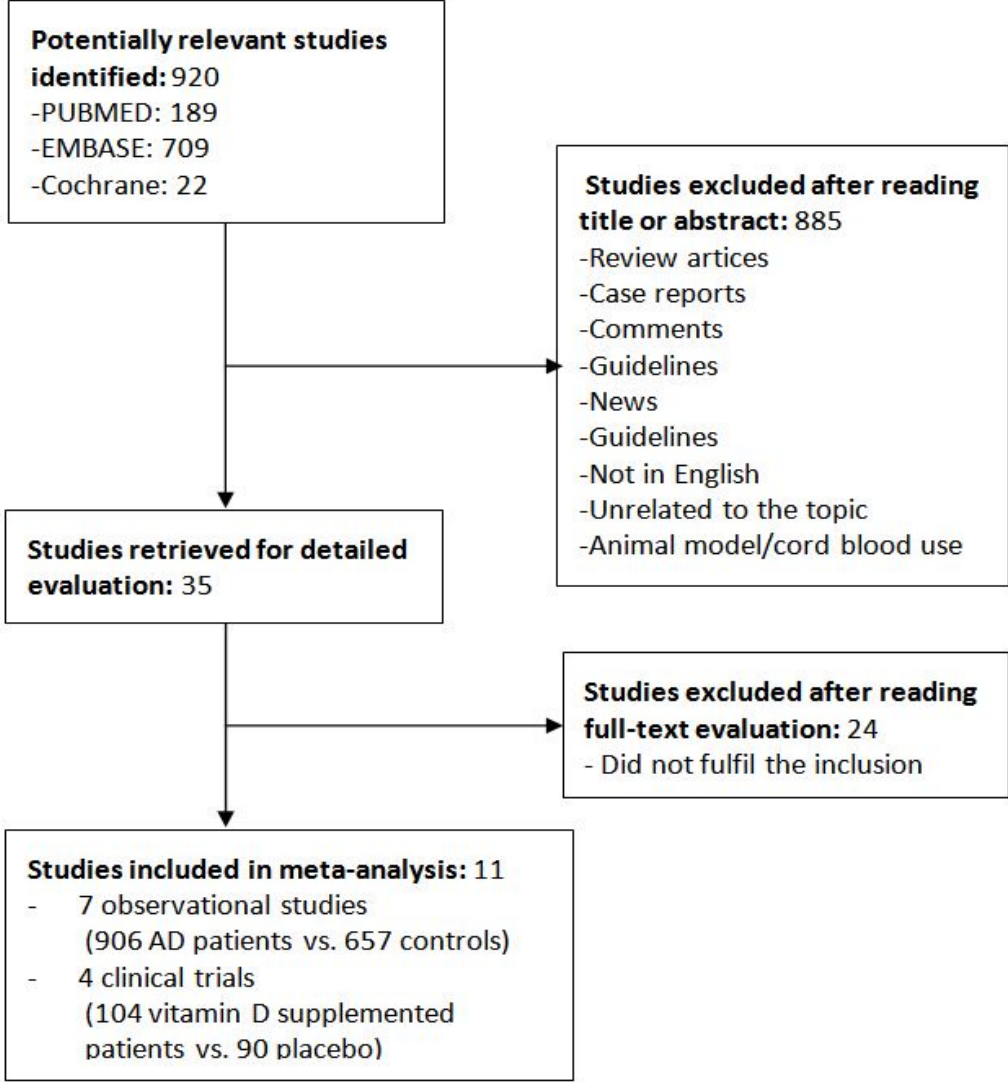

Figure 1. Flow chart of the study selection process. AD: Atopic dermatitis. 


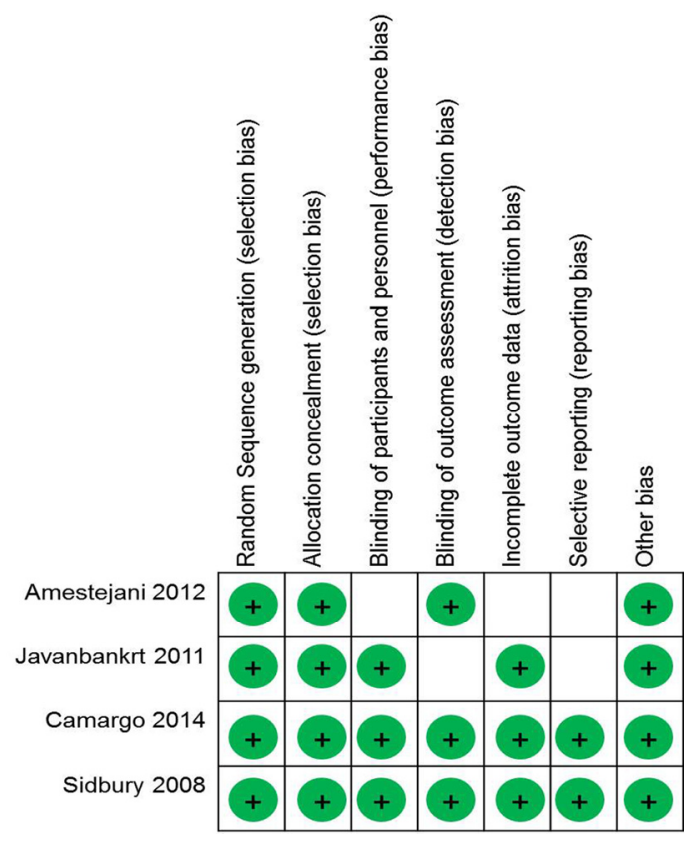

Figure 2. Diagram of the risk of bias of included randomized controlled trials.

\subsection{Comparison of Serum 25(OH)D Levels between AD Patients and Healthy Controls}

Seven studies assessed serum 25(OH)D levels in $A D$ patients and in subjects without AD (control group). The characteristics of the included articles are summarized in Table 2. Overall, $986 \mathrm{AD}$ patients and 657 controls were enrolled from all of the included studies. Two studies $[14,17]$ included individuals of all ages, one study [12] included only adults, and four studies $[13,15,16,18]$ included only pediatric patients. The study by Han et al. [17] included individuals of all ages, but the results were categorized into two groups: children and adults.

Table 2. Summary of the characteristics of the included studies for the comparison of serum 25-hydroxyvitamin D (25(OH)D) levels between AD patients and healthy controls.

\begin{tabular}{|c|c|c|c|c|}
\hline Study & Year & Study Population & Study Size & Location \\
\hline Samochocki et al. [12] & 2013 & $\begin{array}{l}\text { Adults aged } 18-50 \text { years } \\
\text { (mean age: } 29.9 \text { years) }\end{array}$ & $\begin{array}{c}95 \text { cases, } \\
58 \text { control subjects }\end{array}$ & Poland \\
\hline El Taieb et al. [13] & 2013 & $\begin{array}{l}\text { Children aged } 2-12 \text { years } \\
\text { (mean age, AD group: } 6.2 \text { years, } \\
\text { control group: } 6.5 \text { years) }\end{array}$ & $\begin{array}{c}29 \text { cases, } \\
30 \text { control subjects }\end{array}$ & Egypt \\
\hline Noh et al. [14] & 2014 & $\begin{array}{c}\text { All ages (mean age, AD group: } \\
20.8 \text { years, control group: } \\
29.5 \text { years) }\end{array}$ & $\begin{array}{c}82 \text { cases, } \\
49 \text { control subjects }\end{array}$ & Korea \\
\hline Wang et al. [15] & 2014 & $\begin{array}{l}\text { Children (mean age: } 15.5 \text { years, } \\
\text { control group: } 12.3 \text { years) }\end{array}$ & $\begin{array}{c}498 \text { cases, } \\
328 \text { control subjects }\end{array}$ & $\begin{array}{l}\text { Hong } \\
\text { Kong }\end{array}$ \\
\hline Cheon et al. [16] & 2015 & $\begin{array}{l}\text { Children (median age, AD group: } \\
6 \text { years, control group: } 6 \text { years) }\end{array}$ & $\begin{array}{c}91 \text { cases, } \\
32 \text { control subjects }\end{array}$ & Korea \\
\hline Han et al. [17] & 2015 & $\begin{array}{c}\text { All ages (adult group aged } \\
18-51 \text { years, pediatric group aged } \\
12 \text { months }-16 \text { years) }\end{array}$ & $\begin{array}{c}72 \text { cases, } \\
140 \text { control subjects }\end{array}$ & Korea \\
\hline Di Filippo et al. [18] & 2015 & $\begin{array}{l}\text { Children (mean age, } \mathrm{AD} \text { and } \\
\text { control groups: } 4 \text { years) }\end{array}$ & $\begin{array}{c}39 \text { cases, } \\
20 \text { control subjects }\end{array}$ & Italy \\
\hline
\end{tabular}


Compared with the control group, the AD group had lower serum 25(OH)D levels for individuals of all ages in all the included studies (standardized mean difference $=-2.03 \mathrm{ng} / \mathrm{mL} ; 95 \% \mathrm{CI}=-2.98$ to -1.08$)$. The included studies were statistically heterogeneous $\left(I^{2}=98 \%\right.$; Figure $\left.3 \mathrm{~A}\right)$. In the subgroup analysis, the serum $25(\mathrm{OH}) \mathrm{D}$ level was significantly lower in the pediatric AD patients (standardized mean difference $=-3.03 \mathrm{ng} / \mathrm{mL}, 95 \% \mathrm{CI}=-4.76$ to -1.29$)$ than in the controls. The serum $25(\mathrm{OH}) \mathrm{D}$ level was lower in the adult AD group than in the control group; however, this difference was not statistically significant (standard mean difference $=-0.09 \mathrm{ng} / \mathrm{mL}, 95 \% \mathrm{CI}=-0.34$ to 0.16 ; Figure 3B). Statistical heterogeneity was observed among the included studies. In the subgroup analysis, however, only two studies were conducted in adult AD patients, and the total number of enrolled adult AD patients was small (134 AD patients vs. 128 controls for the adults, and 690 AD patients vs. 657 controls for the children).

(A)

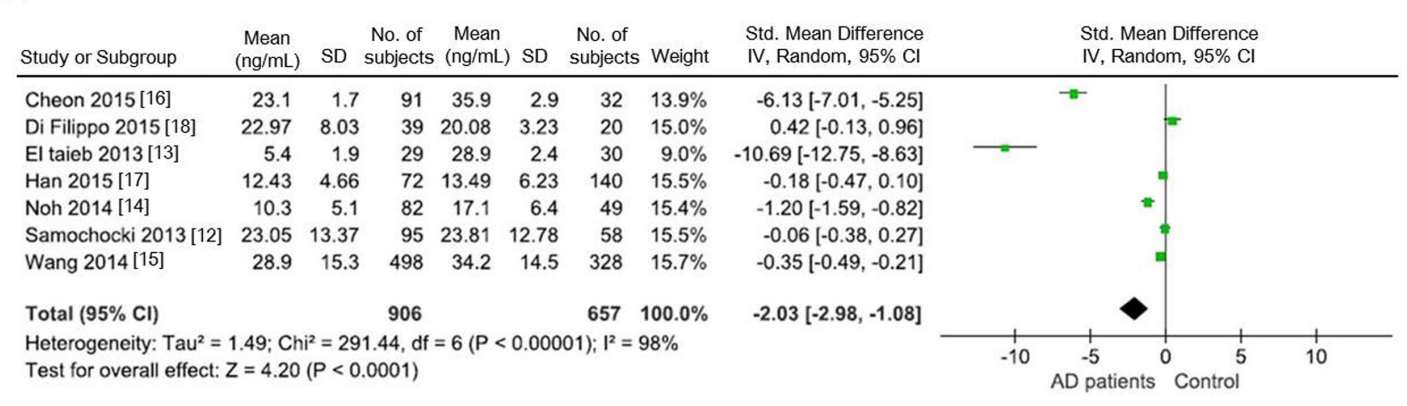

(B)

\begin{tabular}{|c|c|c|c|c|c|c|c|c|c|c|c|c|}
\hline Study or Subgroup & $\begin{array}{c}\text { Mean } \\
(\mathrm{ng} / \mathrm{mL})\end{array}$ & $\mathrm{SD}$ & $\begin{array}{c}\text { No. of } \\
\text { subjects }\end{array}$ & $\begin{array}{c}\text { Mean } \\
(\mathrm{ng} / \mathrm{mL})\end{array}$ & $\mathrm{SD}$ & $\begin{array}{l}\text { No. of } \\
\text { subjects }\end{array}$ & Weight & $\begin{array}{l}\text { Std. Mean Difference } \\
\text { IV, Random, } 95 \% \mathrm{Cl}\end{array}$ & & \multicolumn{3}{|c|}{$\begin{array}{l}\text { Std. Mean Difference } \\
\text { IV, Random, } 95 \% \mathrm{Cl}\end{array}$} \\
\hline \multicolumn{13}{|l|}{ 4.4.1 Adult } \\
\hline Han 2015 (adult) [17] & 10.21 & 3.37 & 39 & 10.73 & 4.4 & 70 & $15.3 \%$ & $-0.13[-0.52,0.26]$ & & & + & \\
\hline $\begin{array}{l}\text { Samochocki } 2013[12] \\
\text { Subtotal }(95 \% \mathrm{Cl})\end{array}$ & 23.05 & 13.37 & $\begin{array}{r}95 \\
134\end{array}$ & 23.81 & 12.78 & $\begin{array}{r}58 \\
128\end{array}$ & $\begin{array}{l}15.4 \% \\
30.7 \%\end{array}$ & $\begin{array}{l}-0.06[-0.38,0.27] \\
-0.09[-0.34,0.16]\end{array}$ & & & $\bar{\square}$ & \\
\hline \multicolumn{13}{|c|}{$\begin{array}{l}\text { Heterogeneity: } \mathrm{Tau}^{2}=0.00 ; \mathrm{Ch}^{2}=0.07, \mathrm{df}=1(P=0.79) ; 1^{2}=0 \% \\
\text { Test for overall effect: } Z=0.67(P=0.50)\end{array}$} \\
\hline \multicolumn{13}{|l|}{ 4.4.2 Children } \\
\hline Choen 2015 [16] & 23.1 & 1.7 & 91 & 35.9 & 2.9 & 32 & $14.0 \%$ & $-6.13[-7.01,-5.25]$ & & $=$ & & \\
\hline Di Filippo 2015 [18] & 22.97 & 8.03 & 39 & 20.08 & 3.23 & 20 & $15.0 \%$ & $0.42[-0.13,0.96]$ & & & $=$ & \\
\hline El taieb 2013 [13] & 5.4 & 1.9 & 29 & 28.9 & 2.4 & 30 & $9.5 \%$ & $-10.69[-12.75,-8.63]$ & $\leftarrow$ & & & \\
\hline Han 2015 (Children) $[17$ & ]15.06 & 4.64 & 33 & 16.25 & 6.6 & 70 & $15.3 \%$ & $-0.20[-0.61,0.22]$ & & & $-\frac{1}{7}$ & \\
\hline Wang $2014[15]$ & 28.9 & 15.3 & 498 & 34.2 & 14.5 & 328 & $15.6 \%$ & $-0.35[-0.49,-0.21]$ & & & = & \\
\hline \multicolumn{13}{|c|}{$\begin{array}{l}\text { Heterogeneity: } \text { Tau}^{2}=3.67 ; \mathrm{Chi}^{2}=269.17, \mathrm{df}=4(\mathrm{P}<0.00001) ; \mathrm{I}^{2}=99 \% \\
\text { Test for overall effect: } Z=3.42(\mathrm{P}=0.0006)\end{array}$} \\
\hline Total $(95 \% \mathrm{Cl})$ & & & 824 & & & 6081 & $100.0 \%$ & $-1.92[-2.93,-0.91]$ & & & & \\
\hline \multicolumn{9}{|c|}{ Heterogeneity: $\mathrm{Tau}^{2}=1.68 ; \mathrm{Chi}^{2}=275.94, \mathrm{df}=6(P<0.00001) ; \mathrm{I}^{2}=98 \%$} & -10 & -5 & patients Control & 10 \\
\hline
\end{tabular}

Figure 3. Serum 25(OH)D levels reported in the observational studies. (A) Comparison of serum $25(\mathrm{OH}) \mathrm{D}$ levels between the AD patients and the controls; (B) Subgroup analysis of vitamin D levels: adult $\mathrm{AD}$ patients and pediatric AD patients.

\subsection{Effect of Vitamin D Supplementation in AD Patients}

Four randomized, double-blind, placebo-controlled trials assessed the efficacy of vitamin D supplementation. The characteristics of the included studies are summarized in Table 3. Two studies [19,20] measured the SCORAD indexes, whereas two of the included studies [21,22] assessed the efficacy of vitamin D supplementation by using EASI score. A meta-analysis of four trials showed that SCORAD index and EASI score decreased significantly after vitamin D supplementation (mean difference $=-5.85,95 \% \mathrm{CI}=-7.66$ to -4.05 ). No statistical heterogeneity was observed among the studies $\left(I^{2}<50 \%\right.$; Figure 4$)$. 
Table 3. Summary of the characteristics of randomized clinical trials investigating the efficacy of vitamin D supplementation.

\begin{tabular}{|c|c|c|c|c|c|c|c|c|c|c|c|}
\hline Study & Year & Study Design & $\begin{array}{c}\text { Study } \\
\text { Population }\end{array}$ & Study Size & $\begin{array}{l}\text { Dose and } \\
\text { Frequency }\end{array}$ & $\begin{array}{l}\text { Supplemented } \\
\text { Vitamin D }\end{array}$ & Duration & Location & $\begin{array}{c}\text { AD } \\
\text { Severity } \\
\text { Assessment }\end{array}$ & $\begin{array}{l}\text { Changes in Severity } \\
\text { Index } \\
\text { (Experimental, Control) }\end{array}$ & $\begin{array}{l}\text { SCORAD or EASI Index } \\
\text { (Experimental } \\
\text { (before } \rightarrow \text { after), } \\
\text { Control (before } \rightarrow \text { after)) }\end{array}$ \\
\hline $\begin{array}{l}\text { Javanbakht } \\
\text { et al. [19] }\end{array}$ & 2011 & $\begin{array}{c}\text { Randomized } \\
\text { double-blind } \\
\text { placebo controlled }\end{array}$ & $\begin{array}{c}\text { All aged, } \\
13-45 \text { years }\end{array}$ & $\begin{array}{l}12 \text { cases, } \\
11 \text { placebo }\end{array}$ & $\begin{array}{l}1600 \mathrm{IU}, \\
\text { daily }\end{array}$ & $\begin{array}{l}\text { Cholecalciferol } \\
\text { (Vitamin D3) }\end{array}$ & 60 days & $\begin{array}{l}\text { Iran, } \\
\text { Tehran }\end{array}$ & SCORAD * & $-12.7 \pm 11.6,-9.4 \pm 10.9$ & $\begin{array}{l}36.0 \pm 3.7 \rightarrow 23.3 \pm 2.8 \\
31.7 \pm 3.5 \rightarrow 22.3 \pm 3.0\end{array}$ \\
\hline $\begin{array}{l}\text { Amestejani } \\
\text { et al. [20] }\end{array}$ & 2012 & $\begin{array}{c}\text { Randomized } \\
\text { double-blind } \\
\text { placebo controlled }\end{array}$ & $>14$ years & $\begin{array}{c}29 \text { cases, } \\
24 \text { placebo }\end{array}$ & $\begin{array}{l}1600 \mathrm{IU}, \\
\text { NR }\end{array}$ & $\begin{array}{l}\text { Cholecalciferol } \\
\text { (Vitamin D3) }\end{array}$ & 2 months & Iran & SCORAD & $-9.5 \pm 3.7,-1.8 \pm 4.8$ & $\begin{array}{r}24.8 \pm 4.1 \rightarrow 15.3 \pm 3.1 \\
25.3 \pm 5.2 \rightarrow 23.46 \pm 4.2\end{array}$ \\
\hline $\begin{array}{l}\text { Sidbury } \\
\text { et al. [21] }\end{array}$ & 2008 & $\begin{array}{c}\text { Randomized } \\
\text { double-blind } \\
\text { placebo controlled }\end{array}$ & $\begin{array}{l}\text { Children, } \\
\text { median: } 7 \\
\text { years }\end{array}$ & $\begin{array}{c}5 \text { cases, } \\
6 \text { placebo }\end{array}$ & $\begin{array}{l}1000 \mathrm{IU}, \\
\text { NR }\end{array}$ & $\begin{array}{c}\text { Ergocalciferol } \\
\text { (Vitamin D2) }\end{array}$ & 1 month & USA & EASI * & $-4.6 \pm N R,-2.2 \pm N R$ & $\mathrm{NR} *$ \\
\hline $\begin{array}{l}\text { Camargo } \\
\text { et al. [22] }\end{array}$ & 2014 & $\begin{array}{c}\text { Randomized } \\
\text { double-blind } \\
\text { placebo controlled }\end{array}$ & $\begin{array}{l}\text { Children, } \\
\text { mean: } 9 \\
\text { years }\end{array}$ & $\begin{array}{c}58 \text { cases, } \\
49 \text { placebo }\end{array}$ & $\begin{array}{l}1000 \mathrm{IU}, \\
\text { daily }\end{array}$ & $\begin{array}{l}\text { Cholecalciferol } \\
\text { (Vitamin D3) }\end{array}$ & 1 month & $\begin{array}{l}\text { Ulaanbaatar, } \\
\text { Mongolia }\end{array}$ & EASI & $-6.5 \pm 8.8,-3.3 \pm 7.6$ & NR \\
\hline
\end{tabular}

* SCORAD: Scoring Atopic Dermatitis, EASI: Eczema Area and Severity Index, NR: not reported.

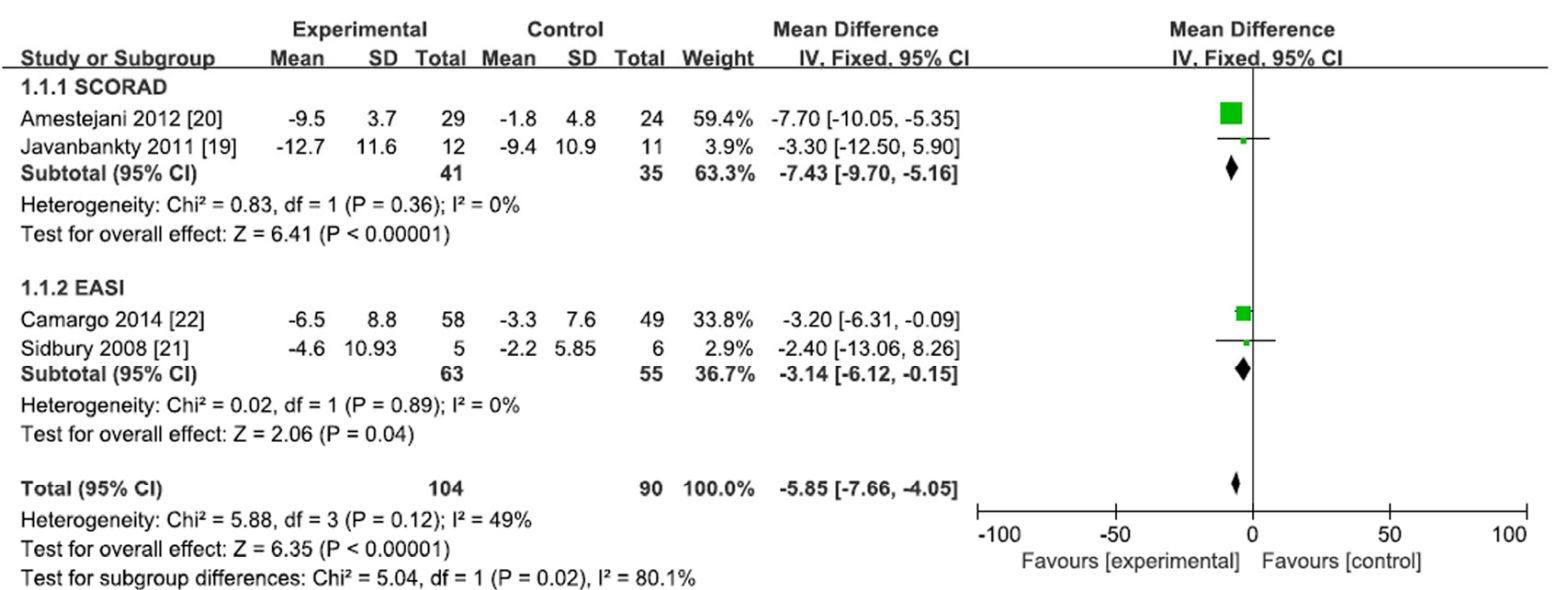

Figure 4. Effect of vitamin D supplementation in the AD patients in the randomized controlled trials. 
In addition, we performed a subgroup analysis. SCORAD index was significantly lower in the vitamin D supplement group (mean difference $=-7.43,95 \% \mathrm{CI}=-9.70$ to $-5.16, I^{2}=0 \%$ ) and EASI score also showed lower after vitamin $\mathrm{D}$ supplementation (mean difference $=-3.14,95 \% \mathrm{CI}=-6.12$ to $-0.15, I^{2}=0 \%$; Figure 4 ).

\section{Discussion}

In the present study, we reviewed and comprehensively summarized case-control studies and randomized controlled studies, providing potentially important information. First, serum 25(OH)D level was lower in the AD patients-particularly in the pediatric patients. In addition, this meta-analysis showed that SCORAD index and EASI score were decreased after vitamin D supplementation as a treatment for AD.

Accumulating studies have identified the pathogenesis of $\mathrm{AD}$, including epidermal barrier disruption, immunologic dysfunction, and personal susceptibility. Based on genetic susceptibility (such as loss of filaggrin gene), the AD patients were found to have a defective skin barrier and dysregulation of the innate immune system, which results in failure of immunologic responses to allergens and microbial pathogens [23,24]. The association between vitamin D deficiency and AD is not clear, but several studies have suggested possible roles of vitamin $\mathrm{D}$ in AD. A previous study demonstrated that antimicrobial peptides such as cathelicidin and $\beta$-defensin increased after vitamin D supplementation in vitro [25]. Liu et al. [26] also found antimicrobial response triggered by the Toll-like receptor and vitamin D-mediated immunity. Clinical trials also showed that vitamin D supplementation promotes cathelicidin production and induces LL-37 expression. Thus, vitamin D promotes antimicrobial activity, with a lower vitamin D level thereby reducing antimicrobial activity and external tolerability to pathogens, making it key in the pathogenesis of $\mathrm{AD}$ [27].

Serum $25(\mathrm{OH}) \mathrm{D}$ level was lower in the AD patients than in the healthy controls across all ages (standardized mean difference $=-2.03 \mathrm{ng} / \mathrm{mL}$ ). Several studies were performed to investigate the association between vitamin D deficiency and AD. However, the association between 25(OH)D and AD is controversial, particularly in adult patients. A large-scale cohort study involving Korean adult patients found that lower serum 25(OH)D levels were associated with AD [28]. On the contrary, a recent Danish cohort study found that serum 25(OH)D level was not associated with $A D$ and other allergic diseases in adults [29]. The above-described results prompted us to perform a sub-group analysis after dividing $\mathrm{AD}$ patients into an adult group and a pediatric group. We found that serum $25(\mathrm{OH}) \mathrm{D}$ level was markedly lower in the pediatric patients. Pediatric AD patients may have an increased risk of allergen penetration through the skin, and most allergies are initiated in childhood. Therefore, we believe that a low vitamin $\mathrm{D}$ level could worsen $\mathrm{AD}$, especially in pediatric patients. In adult $\mathrm{AD}$ patients, the serum $25(\mathrm{OH}) \mathrm{D}$ level was lower than the control group, but this difference was not statistically significant. Our results should be interpreted with caution, because the total number of adult AD patients enrolled in our study was small. Further larger and well-controlled observational studies are required in the future to consolidate the association between serum $25(\mathrm{OH}) \mathrm{D}$ and $\mathrm{AD}$.

The effect of vitamin D supplementation should be considered from two aspects: AD incidence and modification of AD severity [21]. We focused on AD severity, which is associated with disease modification. The present study included four randomized double-blind clinical trials and found that vitamin D supplementation decreased the SCORAD index and EASI score, and that vitamin D supplementation benefits AD patients. However, Norizoe et al. [30] gave vitamin D supplements to mothers during lactation, which did not improve the AD status of the infants. These authors suggested that vitamin D supplementation in infants during breast feeding could increase the risk of food allergy later in life, and supplementation during lactation could have a negative effect on the development of the Th1 and Th2 immune balance [31]. Therefore, vitamin D supplementation should be provided carefully whilst considering the age of the patient, and further studies will be needed.

Two of the included clinical trials (by Sidbury et al. [21] and Camargo et al. [22]) enrolled pediatric patients who had a history of AD worsening in the winter, and both studies showed that EASI score 
was decreased after vitamin D supplementation. These authors explained that the lower sun exposure in the winter leads to vitamin D deficiency, and lower vitamin D levels could worsen AD. Similarly, a recent study reported that birth in winter season may be associated with AD, which suggested that inadequate sunlight exposure (associated with lower vitamin D status) increased the risk of AD [32]. Accumulating data have proven that phototherapy is the most efficacious, well-tolerated treatment option for AD. Ultraviolet B radiation suppresses the expressions of pro-inflammatory cytokines such as interleukin (IL)-12, IL-2, and interferon- $\gamma$, and stimulates IL-10 production via keratinocytes, thereby reducing expression levels of pro-inflammatory cytokines and suppressing the growth of natural killer cells $[33,34]$. Thus, vitamin D supplementation can compensate for the reduced ultraviolet exposure and alleviate $\mathrm{AD}$ severity. From these data, we assume that vitamin $\mathrm{D}$ supplementation is effective in AD patients, and that the characteristics of their condition-including seasonal variation of severity - should be considered.

The results of this study should be interpreted with caution, because of the several limitations of our meta-analysis. First, information about basal 25(OH)D levels and changes in 25(OH)D level after vitamin D supplementation was lacking. Heaney et al. [35] suggested a guideline for clinical studies of nutrient effects. The author emphasized the measurement of basal levels of nutrients, and that when performing meta-analysis, all the included studies should have similar basal nutrient levels. Owing to the inadequate information from the included articles, we could not provide the exact status of 25(OH)D level. Javanbakht et al. [19] did not report basal 25(OH)D levels in detail, but they reported the prevalence of vitamin D deficiency, which was $72.7 \%$ in the placebo group and $81.8 \%$ in the vitamin D supplemented group. Amestejani et al. [20] also measured 25(OH)D level and reported a mean 25(OH)D level of $9.8 \mathrm{ng} / \mathrm{mL}$ before vitamin D supplementation, which was categorized as vitamin D-deficient status. Studies performed by Camargo et al. [22] and Sidbury et al. [21] did not provide data on $25(\mathrm{OH}) \mathrm{D}$ levels. However, these studies included the AD patients who had a history of worsening in the winter season, and the authors assumed that the worsening in the winter season was associated with vitamin D deficiency. Thus, we assumed that the included AD patients in this meta-analysis probably had vitamin D deficiency and similar 25(OH)D levels. Second, we did not adjust for potential confounding factors of the serum $25(\mathrm{OH}) \mathrm{D}$ level in the selected populations, such as altitude, latitude, sun exposure, seasonal variation, level of outdoor activities, and dietary vitamin D intake [36]. Third, significant interstudy heterogeneity was present, which can be partially attributed to the confounding factors. The study included uncontrollable factors of AD treatment, such as usage of topical steroid and confounding factors as mentioned earlier. Finally, this meta-analysis included a small number of randomized clinical trials in the assessments of the efficacy of vitamin D supplementation. However, we thought a meta-analysis would still be worthwhile to determine the overall association between serum 25(OH)D and SCORAD index. Further larger studies that include a subgroup analysis of infant, pediatric, and adult AD patients are required to clarify the benefits of vitamin D supplementation.

In conclusion, this meta-analysis summarized the evidence for the role of vitamin $\mathrm{D}$ in $\mathrm{AD}$ patients. Serum 25(OH)D level was lower in the AD patients than in the controls, and the subgroup analysis showed that the difference in serum $25(\mathrm{OH}) \mathrm{D}$ level was significant in the pediatric patients. In addition, in comparison with a placebo group, vitamin D supplementation decreased AD severity and improved the symptoms and clinical signs of AD. However, the specific mechanisms underlying the role of vitamin $\mathrm{D}$ in this relationship are still unclear. Further studies are required to clarify the molecular pathways and mechanisms underlying the effects of vitamin D, with large-scale clinical trials needed to assess the effect of vitamin D treatment on AD outcomes.

Author Contributions: Min Jung Kim designed the study and, collected the data, performed the initial analysis, and drafted the initial manuscript. Soo Nyung Kim performed the statistical analyses, and reviewed and revised the manuscript. Yang Won Lee conceptualized and designed the study, collected the data, and reviewed and revised the manuscript. Yong Beom Choe and Kyu Joong Ahn critically reviewed the manuscript. All the authors approved the final manuscript as submitted.

Conflicts of Interest: The authors declare no conflict of interests. 


\section{References}

1. Bieber, T. Atopic dermatitis. N. Engl. J. Med. 2008, 358, 1483-1494. [CrossRef] [PubMed]

2. Williams, H.; Robertson, C.; Stewart, A.; Ait-Khaled, N.; Anabwani, G.; Anderson, R.; Asher, I.; Beasley, R.; Bjorksten, B.; Burr, M.; et al. Worldwide variations in the prevalence of symptoms of atopic eczema in the international study of asthma and allergies in childhood. J. Allergy Clin. Immunol. 1999, 103, 125-138. [CrossRef]

3. Leung, D.Y.; Bieber, T. Atopic dermatitis. Lancet 2003, 361, 151-160. [CrossRef]

4. Eichenfield, L.F.; Tom, W.L.; Berger, T.G.; Krol, A.; Paller, A.S.; Schwarzenberger, K.; Bergman, J.N.; Chamlin, S.L.; Cohen, D.E.; Cooper, K.D.; et al. Guidelines of care for the management of atopic dermatitis: Section 2. Management and treatment of atopic dermatitis with topical therapies. J. Am. Acad. Dermatol. 2014, 71, 116-132. [CrossRef] [PubMed]

5. Bath-Hextall, F.J.; Jenkinson, C.; Humphreys, R.; Williams, H.C. Dietary supplements for established atopic eczema. Cochrane Database Syst. Rev. 2012, 2, CD005205.

6. Moher, D.; Liberati, A.; Tetzlaff, J.; Altman, D.G.; PRISMA Group. Preferred reporting items for systematic reviews and meta-analyses: The prisma statement. BMJ 2009, 339, b2535. [CrossRef] [PubMed]

7. Wells, G.; Shea, B.; O'Connel, D.; Peterson, J.; Welch, V.; Losos, M.; Tugwell, P. The Newcastle-Ottawa Scale (NOS) for Assessing the Quality of Nonrandomised Studies in Meta-Analyses; Department of Epidemiology and Community Medicine, University of Ottawa: Ottawa, ON, Canada, 2013.

8. Cochrane Handbook for Systematic Review of Interventions. 2011. Available online: www.handbook. cochrane.org (accessed on 1 July 2015).

9. Higgins, J.P.; Thompson, S.G.; Deeks, J.J.; Altman, D.G. Measuring inconsistency in meta-analyses. BMJ 2003, 327, 557-560. [CrossRef] [PubMed]

10. Egger, M.; Smith, G.; Altman, D.G. Systematic Reviews in Health Care: Meta-Analysis in Context, 2nd ed.; BMJ Publishing Group: London, UK, 2001.

11. Sterne, J.A.; Egger, M. Funnel plots for detecting bias in meta-analysis: Guidelines on choice of axis. J. Clin. Epidemiol. 2001, 54, 1046-1055. [CrossRef]

12. Samochocki, Z.; Bogaczewicz, J.; Jeziorkowska, R.; Sysa-Jedrzejowska, A.; Glinska, O.; Karczmarewicz, E.; McCauliffe, D.P.; Wozniacka, A. Vitamin D effects in atopic dermatitis. J. Am. Acad. Dermatol. 2013, 69, 238-244. [CrossRef] [PubMed]

13. El Taieb, M.A.; Fayed, H.M.; Aly, S.S.; Ibrahim, A.K. Assessment of serum 25-hydroxyvitamin D levels in children with atopic dermatitis: Correlation with scorad index. Dermatitis 2013, 24, 296-301. [CrossRef] [PubMed]

14. Noh, S.; Park, C.O.; Bae, J.M.; Lee, J.; Shin, J.U.; Hong, C.S.; Lee, K.H. Lower vitamin D status is closely correlated with eczema of the head and neck. J. Allergy Clin. Immunol. 2014, 133, 1767.e6-1770.e6. [CrossRef] [PubMed]

15. Wang, S.S.; Hon, K.L.; Kong, A.P.; Pong, H.N.; Wong, G.W.; Leung, T.F. Vitamin D deficiency is associated with diagnosis and severity of childhood atopic dermatitis. Pediatr. Allergy Immunol. 2014, 25, 30-35. [CrossRef] [PubMed]

16. Cheon, B.R.; Shin, J.E.; Kim, Y.J.; Shim, J.W.; Kim, D.S.; Jung, H.L.; Park, M.S.; Shim, J.Y. Relationship between serum 25-hydroxyvitamin D and interleukin-31 levels, and the severity of atopic dermatitis in children. Korean J. Pediatr. 2015, 58, 96-101. [CrossRef] [PubMed]

17. Han, T.Y.; Kong, T.S.; Kim, M.H.; Chae, J.D.; Lee, J.H.; Son, S.J. Vitamin D status and its association with the scorad score and serum LL-37 level in korean adults and children with atopic dermatitis. Ann. Dermatol. 2015, 27, 10-14. [CrossRef] [PubMed]

18. Di Filippo, P.; Scaparrotta, A.; Rapino, D.; Cingolani, A.; Attanasi, M.; Petrosino, M.I.; Chuang, K.; Di Pillo, S.; Chiarelli, F. Vitamin D supplementation modulates the immune system and improves atopic dermatitis in children. Int. Arch. Allergy Immunol. 2015, 166, 91-96. [CrossRef] [PubMed]

19. Javanbakht, M.H.; Keshavarz, S.A.; Djalali, M.; Siassi, F.; Eshraghian, M.R.; Firooz, A.; Seirafi, H.; Ehsani, A.H.; Chamari, M.; Mirshafiey, A. Randomized controlled trial using vitamins E and D supplementation in atopic dermatitis. J. Dermatol. Treat. 2011, 22, 144-150. [CrossRef] [PubMed] 
20. Amestejani, M.; Salehi, B.S.; Vasigh, M.; Sobhkhiz, A.; Karami, M.; Alinia, H.; Kamrava, S.K.; Shamspour, N.; Ghalehbaghi, B.; Behzadi, A.H. Vitamin D supplementation in the treatment of atopic dermatitis: A clinical trial study. J. Drugs Dermatol. 2012, 11, 327-330. [PubMed]

21. Sidbury, R.; Sullivan, A.F.; Thadhani, R.I.; Camargo, C.A., Jr. Randomized controlled trial of vitamin D supplementation for winter-related atopic dermatitis in Boston: A pilot study. Br. J. Dermatol. 2008, 159, 245-247. [CrossRef] [PubMed]

22. Camargo, C.A., Jr.; Ganmaa, D.; Sidbury, R.; Erdenedelger, K.; Radnaakhand, N.; Khandsuren, B. Randomized trial of vitamin D supplementation for winter-related atopic dermatitis in children. J. Allergy Clin. Immunol. 2014, 134, 831.e1-835.e1. [CrossRef] [PubMed]

23. Elias, P.M.; Hatano, Y.; Williams, M.L. Basis for the barrier abnormality in atopic dermatitis: Outside-inside-outside pathogenic mechanisms. J. Allergy Clin. Immunol. 2008, 121, 1337-1343. [CrossRef] [PubMed]

24. Searing, D.A.; Leung, D.Y. Vitamin D in atopic dermatitis, asthma and allergic diseases. Immunol. Allergy Clin. N. Am. 2010, 30, 397-409. [CrossRef] [PubMed]

25. Wang, T.T.; Nestel, F.P.; Bourdeau, V.; Nagai, Y.; Wang, Q.; Liao, J.; Tavera-Mendoza, L.; Lin, R.; Hanrahan, J.W.; Mader, S.; et al. Cutting edge: 1,25-dihydroxyvitamin D3 is a direct inducer of antimicrobial peptide gene expression. J. Immunol. 2004, 173, 2909-2912. [CrossRef] [PubMed]

26. Liu, P.T.; Stenger, S.; Li, H.; Wenzel, L.; Tan, B.H.; Krutzik, S.R.; Ochoa, M.T.; Schauber, J.; Wu, K.; Meinken, C.; et al. Toll-like receptor triggering of a vitamin D-mediated human antimicrobial response. Science 2006, 311, 1770-1773. [CrossRef] [PubMed]

27. Leung, D.Y.; Boguniewicz, M.; Howell, M.D.; Nomura, I.; Hamid, Q.A. New insights into atopic dermatitis. J. Clin. Investig. 2004, 113, 651-657. [CrossRef] [PubMed]

28. Cheng, H.M.; Kim, S.; Park, G.H.; Chang, S.E.; Bang, S.; Won, C.H.; Lee, M.W.; Choi, J.H.; Moon, K.C. Low vitamin D levels are associated with atopic dermatitis, but not allergic rhinitis, asthma, or ige sensitization, in the adult Korean population. J. Allergy Clin. Immunol. 2014, 133, 1048-1055. [CrossRef] [PubMed]

29. Thuesen, B.H.; Heede, N.G.; Tang, L.; Skaaby, T.; Thyssen, J.P.; Friedrich, N.; Linneberg, A. No association between vitamin $\mathrm{D}$ and atopy, asthma, lung function or atopic dermatitis: A prospective study in adults. Allergy 2015, 70, 1501-1504. [CrossRef] [PubMed]

30. Norizoe, C.; Akiyama, N.; Segawa, T.; Tachimoto, H.; Mezawa, H.; Ida, H.; Urashima, M. Increased food allergy and vitamin D: Randomized, double-blind, placebo-controlled trial. Pediatr. Int. 2014, 56, 6-12. [CrossRef] [PubMed]

31. Back, O.; Blomquist, H.K.; Hernell, O.; Stenberg, B. Does vitamin D intake during infancy promote the development of atopic allergy? Acta Derm. Venereol. 2009, 89, 28-32. [CrossRef] [PubMed]

32. Hwang, J.M.; Oh, S.H.; Shin, M.Y. The relationships among birth season, sunlight exposure during infancy, and allergic disease. Korean J. Pediatr. 2016, 59, 218-225. [CrossRef] [PubMed]

33. Clayton, T.H.; Clark, S.M.; Turner, D.; Goulden, V. The treatment of severe atopic dermatitis in childhood with narrowband ultraviolet B phototherapy. Clin. Exp. Dermatol. 2007, 32, 28-33. [CrossRef] [PubMed]

34. Walters, I.B.; Ozawa, M.; Cardinale, I.; Gilleaudeau, P.; Trepicchio, W.L.; Bliss, J.; Krueger, J.G. Narrowband (312-nm) UV-B suppresses interferon gamma and interleukin (IL) 12 and increases IL-4 transcripts: Differential regulation of cytokines at the single-cell level. Arch. Dermatol. 2003, 139, 155-161. [CrossRef] [PubMed]

35. Heaney, R.P. Guidelines for optimizing design and analysis of clinical studies of nutrient effects. Nutr. Rev. 2014, 72, 48-54. [CrossRef] [PubMed]

36. Lu, C.; Yang, J.; Yu, W.; Li, D.; Xiang, Z.; Lin, Y.; Yu, C. Association between 25(OH)D level, ultraviolet exposure, geographical location, and inflammatory bowel disease activity: A systematic review and meta-analysis. PLoS ONE 2015, 10, e0132036. [CrossRef] [PubMed]

(C) 2016 by the authors; licensee MDPI, Basel, Switzerland. This article is an open access article distributed under the terms and conditions of the Creative Commons Attribution (CC-BY) license (http:/ / creativecommons.org/licenses/by/4.0/). 